\title{
Methane production potentials, pathways, and communities of methanogens in vertical sediment profiles of river Sitka
}

\author{
Václav Mach ${ }^{1 \dagger}$, Martin B. Blaser ${ }^{2 * t}$, Peter Claus ${ }^{2}$, Prem P. Chaudhary ${ }^{1}$ and Martin Rulik ${ }^{1}$ \\ 1 Department of Ecology and Environmental Science, Faculty of Science, Palacky University, Olomouc, Czech Republic, \\ ${ }^{2}$ Department of Biogeochemistry, Max Planck Institute for Terrestrial Microbiology, Marburg, Germany
}

OPEN ACCESS

Edited by:

Gary M. King,

Louisiana State University, USA

Reviewed by:

Claudia Knief,

University of Bonn, Germany

Yin Chen,

University of Warwick, UK

*Correspondence:

Martin B. Blaser,

Max Planck Institute for Terrestrial Microbiology, Karl-von-Frisch-Str. 10,

35043 Marburg, Germany blaserm@mpi-marburg.mpg.de

${ }^{t}$ These authors have contributed equally to this work.

Specialty section:

This article was submitted to Terrestrial Microbiology, a section of the journal

Frontiers in Microbiology

Received: 27 February 2015 Accepted: 07 May 2015

Published: 21 May 2015

Citation:

Mach V, Blaser MB, Claus $P$, Chaudhary PP and Rulik M (2015) Methane production potentials, pathways, and communities of methanogens in vertical sediment profiles of river Sitka.

Front. Microbiol. 6:506. doi: 10.3389/fmicb.2015.00506
Biological methanogenesis is linked to permanent water logged systems, e.g., rice field soils or lake sediments. In these systems the methanogenic community as well as the pathway of methane formation are well-described. By contrast, the methanogenic potential of river sediments is so far not well-investigated. Therefore, we analyzed (a) the methanogenic potential (incubation experiments), (b) the pathway of methane production (stable carbon isotopes and inhibitor studies), and (c) the methanogenic community composition (terminal restriction length polymorphism of $m c r A$ ) in depth profiles of sediment cores of River Sitka, Czech Republic. We found two depth-related distinct maxima for the methanogenic potentials (a) The pathway of methane production was dominated by hydrogenotrophic methanogenesis (b) The methanogenic community composition was similar in all depth layers (c) The main TRFs were representative for Methanosarcina, Methanosaeta, Methanobacterium, and Methanomicrobium species. The isotopic signals of acetate indicated a relative high contribution of chemolithotrophic acetogenesis to the acetate pool.

Keywords: methane production potential, river sediment, stable carbon isotope, isotope fractionation, depth profile, methyl fluoride, mcrA, T-RFLP

\section{Introduction}

Biogenic methane production is carried out by highly specialized, oxygen sensitive methanogenic archaea. Usually methanogenesis is therefore restricted to water-logged systems like freshwater sediments, rice field soils or gut systems (Ciais et al., 2014). Rivers as turbulent systems usually have well-aerated water bodies. Hence they are not considered to be an important source of atmospheric methane (Conrad, 2009; Ciais et al., 2014). Even when the methane emission of different fresh water systems (lakes, wetlands etc.) is compared, the emission rates of rivers are usually low (Table 1).

Methane emission from fresh water systems is usually estimated using the $\mathrm{CH}_{4}$ released from open water bodies to the atmosphere. These kind of measurements are showing high spatial fluctuations of methane concentrations (Berger and Heyer, 1989; Lilley et al., 1996; Moura et al., 2008; Wang et al., 2009; Gar'Kusha et al., 2010; Striegl et al., 2012; Musenze et al., 2014) as well as seasonal dynamics (Sanders et al., 2007; Gar'Kusha et al., 2010; Musenze et al., 2014).

However, methane measurements of river water body may not give a conclusive picture of the methanogenic potential of river ecosystems, since the well-aerated water bodies render optimal conditions for methanotrophic bacteria possibly scavenging a large portion of the methane 
TABLE 1 | Methane emissions from wetlands.

\begin{tabular}{|c|c|c|}
\hline River & $\begin{array}{l}\text { Methane emission rate } \\
\qquad\left(\mathrm{mg} \mathrm{CH}_{4} \mathrm{~m}^{-2} \mathrm{~h}^{-1}\right)\end{array}$ & References \\
\hline River (Nome Creek) ${ }^{a}$ & 3.5 & Crawford et al., 2013 \\
\hline River (Sitka) & $0.3-1.6$ & Hlavacova et al., 2006 \\
\hline Rivers $^{b}$ & $0.01-6.67$ & Bastviken et al., 2011 \\
\hline Rivers & 10.5 & $\begin{array}{l}\text { Ortiz-Llorente and } \\
\text { Alvarez-Cobelas, } 2012\end{array}$ \\
\hline Lakes & 18.1 & $\begin{array}{l}\text { Ortiz-Llorente and } \\
\text { Alvarez-Cobelas, } 2012\end{array}$ \\
\hline Wetlands & 13.6 & $\begin{array}{l}\text { Ortiz-Llorente and } \\
\text { Alvarez-Cobelas, } 2012\end{array}$ \\
\hline Estuaries & 3.3 & $\begin{array}{l}\text { Ortiz-Llorente and } \\
\text { Alvarez-Cobelas, } 2012\end{array}$ \\
\hline
\end{tabular}

${ }^{a}$ Given as $58.2 \mathrm{nmol} \mathrm{CH}_{4} \mathrm{~m}^{-2} \mathrm{~s}^{-1}$ b Calculated from Supplementary Material.

produced in the anoxic parts of the river sediment. Indeed the methane concentrations in the sediment are usually two orders of magnitude higher than in the surface water as can be seen for our study site river Sitka (Hlavacova et al., 2005; Rulik et al., 2013) and several other river sediments (Zaiss, 1981; De Angelis and Scranton, 1993; Trimmer et al., 2009; Gar'Kusha et al., 2010).

In contrast to these in situ measurements, which to some extent may be influenced by aerobic methanotrophic activities, the methanogenic production potential of river sediments can be obtained with incubation experiments under strict anoxic conditions in the laboratory. Such experiments have so far only been conducted for mixed top sediments (Jones et al., 1995; Avery and Martens, 1999). In river Sitka preliminary methane production potentials have been estimated with short time incubations under substrate additions (ca $8 \mu \mathrm{M}$ acetate) (Rulik et al., 2013). Since earlier reports in sediment profiles show vertically dispersed methane concentrations (De Angelis and Scranton, 1993; Schindler and Krabbenhoft, 1998; Gar'Kusha et al., 2010; Chen and Yin, 2013) we decided to test the methanogenic potential of different depth layers of two sediment cores to define whether these differences are due to different methanogenic potentials.

In addition we aimed to differentiate the underlying pathway of methane production. In the well-studied systems (e.g., rice paddies and lake sediments) methane emission can be linked to two dominating processes: acetoclastic (Equation 1) and hydrogenotrophic (Equation 2) methanogenesis:

$$
\begin{gathered}
\mathrm{CH}_{3} \mathrm{COOH} \rightarrow \mathrm{CO}_{2}+\mathrm{CH}_{4} \\
\mathrm{CO}_{2}+4 \mathrm{H}_{2} \rightarrow 2 \mathrm{H}_{2} \mathrm{O}+\mathrm{CH}_{4}
\end{gathered}
$$

To distinguish the two dominant methanogenic pathways the natural abundance of stable carbon isotopes can be used if the $\delta^{13} \mathrm{C}$ of methane and of its precursors and the methanogenic fractionation factors are known (Conrad, 2005). The acetoclastic methanogenesis expresses a smaller kinetic isotopic effect (KIE = 1.009-1.027) (Gelwicks et al., 1994; Penning et al., 2006; Goevert and Conrad, 2009) than the hydrogenotrophic methane formation (KIE $=1.045-1.073$ ) (Valentine et al., 2004). The inhibition of acetoclastic methanogenesis by methyl fluoride
$\left(\mathrm{CH}_{3} \mathrm{~F}\right)$ allows quantifying the contribution of both pathways (Janssen and Frenzel, 1997; Conrad et al., 2011).

While the acetoclastic pathway is dominating in e.g., rice paddy soils [up to $67 \%$ of methane release (Conrad, 1999)] freshwater sediments and gut environments are dominated by hydrogen driven methanogenesis (Conrad, 1999). The hydrogenotrophic contribution to methane relase for White Oak River sediments was reported to be 37-39\% (Avery and Martens, 1999).

As a third aspect we were interested in quantifying the methanogenic community in river sediment profiles and contrast these findings to well-described ecosystems: Lake sediments are dominated by Methanomicrobiales and Methanosaetaceae. They show gradual vertical changes in methanogenic potential, pathway usage and community composition (Chan et al., 2005). Investigations of mudflat sediments of Yangtze River estuary, China showed a dominance of Methanomicrobiales and Methanosarcinales (Zeleke et al., 2013). In freshwater systems Methanomicrobiales have been shown to increase in relative abundance with depth while Methanosarcinales/Methanosaetaceae decrease (Chan et al., 2005; Zeleke et al., 2013). Oxygenated upland soils contain a less developed methanogenic community than permanently water-logged systems and are dominated by Methanocellales and Methanosarcinales (Angel et al., 2012). Rice field soils are generally characterized by the most complex methanogenic community (Chin et al., 1999; Lueders et al., 2001; Ramakrishnan et al., 2001), which has been attributed to the seasonal change of oxic and anoxic conditions. We speculated that the methanogenic community of river sediments will be similar to lake sediments.

In this study, we investigated the methanogenic potential, pathway usage and community structure in river sediment depth profiles. We had three main objectives: (1) we wanted to investigate how the potential methane production rates differ over a vertical profile of two sediment cores in order to validate the potential methane emission rates of river sediment compared to other water logged systems. (2) We wanted to characterize the underlying pathway usage of methane production using the natural stable carbon isotope signals. (3) We were interested in comparing the methanogenic community of river sediments to community profiles of other well-characterized soil systems.

In general we hypothesized that river sediments will share some common features with other freshwater sediments but may also have distinct characteristics due to the water movement and the higher oxygen load of the overlaying water.

\section{Methods}

\section{Sampling Site}

The sampling site is situated ca $10 \mathrm{~km}$ north of the city Olomouc in an agricultural field area. Stream width ranges between 4 and $6 \mathrm{~m}$ during a year. Bottom sediments are composed of clay, sand and gravel having a median grain size of $0.2 \mathrm{~mm}$. More physicochemical parameters (e.g., grain median size, organic carbon content, dissolved $\mathrm{O}_{2}$, DOC, interstitial, $\mathrm{CH}_{4}$ concentration) in the sediments have already been reported (Buriankova et al., 2012) as locality IV. 


\section{Sediment Sampling}

Two sediments cores ( $60 \mathrm{~cm}$ deep) were collected using the freeze core method (Bretschko and Klemens, 1986) at morning in April 2012. Sediment cores were split up in layers of $10 \mathrm{~cm}$, sieved with distilled deionized water to $1 \mathrm{~mm}$ grain size and stored at $4^{\circ} \mathrm{C}$ under river water in closed plastic jars.

\section{Incubation Experiments}

For determining the methanogenic potential of sediment and carbon isotopic composition of methane and carbon dioxide, the samples were incubated in triplicates under wet anoxic conditions: $5 \mathrm{~g}$ of wet sediment samples were supplemented with $2 \mathrm{ml}$ of distilled water and placed in $27-\mathrm{ml}$ pressure tubes, closed with butyl rubber stoppers and incubated under $\mathrm{N}_{2}$ at $25^{\circ} \mathrm{C}$; if needed $3 \%\left(\mathrm{v} / \mathrm{v}\right.$ of the headspace) methyl fluoride $\left(\mathrm{CH}_{3} \mathrm{~F}\right)$ was added to specifically inhibit acetoclastic methanogenesis (Janssen and Frenzel, 1997; Conrad and Klose, 1999). Gas subsamples $(0.1-0.4 \mathrm{ml})$ were taken repeatedly from the headspace using a gas-tight syringe (VICI) and analyzed for concentration and $\delta^{13} \mathrm{C}$ of $\mathrm{CH}_{4}$ and $\mathrm{CO}_{2}$. Methane production potentials were calculated as slope of the methane concentration over time using at least three data points during the linear phase of methane release. The production potentials are given in $\mathrm{nmol} \mathrm{CH}_{4}$ per gram dry weight (DW) per day. The water content of fresh samples was approximately $24.6 \% \pm 4$.

At the end of the incubation, the vials were sacrificed, sediments were centrifuged and the supernatants were filtered through $0.2-\mu \mathrm{m}$ polytetrafluoroethylene (PTFE) membrane filters and stored at $-20^{\circ} \mathrm{C}$ for later analysis of concentration and $\delta^{13} \mathrm{C}$ of acetate (and other fatty acids).

\section{In-Situ Gas Measurements}

At morning time in October 2012, sampling of gas ebullition from river sediments was carried out at the same stream stretch from where sediment cores were collected. Ebullition samples were taken in water depths varying from 30 to $80 \mathrm{~cm}$ according to spatial changes in the water level. To collect the samples we modified the method described by Martens et al. (1992). The gas was collected in an inverted funnel $(20 \mathrm{~cm}$ diameter) and transferred into a $6 \mathrm{ml}$ gas tight syringe. The gas samples ( $2 \mathrm{ml}$ ) were then transferred into $12-\mathrm{ml}$ glass vials containing $\mathrm{N}_{2}$ previously sealed with butyl rubber stopper. Nine samples were sent for carbon isotopic analysis of methane and carbon dioxide to the Max-Planck Institute for terrestrial Microbiology, Marburg (Germany).

\section{Chemical and Isotopic Analyses}

$\mathrm{CH}_{4}$ was analyzed by gas chromatography (GC) using a flame ionization detector (Shimadzu, Kyoto, Japan). $\mathrm{CO}_{2}$ was analyzed after conversion to $\mathrm{CH}_{4}$ with a methanizer (Ni-catalyst at $350^{\circ} \mathrm{C}$, Chrompack, Middelburg, Netherlands). Isotope measurements of ${ }^{13} \mathrm{C} /{ }^{12} \mathrm{C}$ in gas samples were performed on a gas chromatograph combustion isotope ratio mass spectrometer (GC-C-IRMS) system (Thermo Fisher Scientific, Bremen, Germany). The principle operation was described by Brand (1996). The gaseous compounds were first separated in a Hewlett Packard 6890 GC using a Pora Plot Q column $(27.5$ m length, $0.32 \mathrm{~mm}$ internal diameter, and $10 \mu \mathrm{m}$ film thickness; Chromopack Frankfurt, Germany) at $30^{\circ} \mathrm{C}$ and $\mathrm{He}(99.996 \%$ purity; $2.6 \mathrm{ml} / \mathrm{min}$ ) as carrier gas. The sample was run through the Finnigan Standard GC Combustion Interface III and the isotope ratio of ${ }^{13} \mathrm{C} /{ }^{12} \mathrm{C}$ was analyzed in the IRMS (Finnigan MAT Deltaplus). The reference gas was $\mathrm{CO}_{2}$ (99.998\% purity) (Air Liquide, Düsseldorf, Germany), calibrated with the working standard methylstearate (Merck). The latter was intercalibrated at the Max Planck Institute for Biogeochemistry, Jena, Germany (courtesy of W. A. Brand) against the NBS-22 and USGS-24 standards and reported in the delta notation vs. Vienna Pee Dee Belemnite.

$$
\delta^{13} \mathrm{C}=10^{3}\left(\mathrm{R}_{\text {sample }} / \mathrm{R}_{\text {standard }}-1\right)
$$

with $\mathrm{R}={ }^{13} \mathrm{C} /{ }^{12} \mathrm{C}$ of sample and standard, respectively.

Isotopic analysis and quantification of acetate were performed on a high pressure liquid chromatography (HPLC) system (Spectra System P1000, Thermo Fisher Scientific, San Jose, CA, USA; Mistral, Spark, Emmen, the Netherlands) equipped with an ion-exclusion column (Aminex HPX-87-H, BioRad, München, Germany) and coupled to Finnigan LC IsoLink (Thermo Fisher Scientific, Bremen, Germany) as described (Krummen et al., 2004). Isotope ratios were detected on an IRMS (Finnigan MAT Deltaplus Advantage).

The $\delta^{13} \mathrm{C}$ in the organic matter was analyzed at the University of Göttigen (Germany) using an elemental analyzer (Fisons EA 1108) coupled to a mass spectrometer. The $\mathrm{C}, \mathrm{N}$, and $\mathrm{H}$ content of the sediments were quantified on a CHNS-element analyzer by the Analytical Chemical Laboratory of the University of Marburg.

\section{Calculations}

The carbon isotopic signature was given in the delta notation relative to the Vienna Pee Dee Belemnite (V-PDB) standard. The fractionation factor $\alpha$ for a reaction $\mathrm{A} \rightarrow \mathrm{B}$ are defined after (Hayes, 1993):

$$
\alpha_{\mathrm{A}, \mathrm{B}}=\left(\delta^{13} \mathrm{C}_{\mathrm{A}}+10^{3}\right) /\left(\delta^{13} \mathrm{C}_{\mathrm{B}}+10^{3}\right)
$$

Isotopic calculations of fractionation factors and estimation of the approximate partition of hydrogenotrophic methanogenesis of the total methanogenesis were calculated according to Conrad (2005):

The apparent fractionation factor $\left(\alpha_{\mathrm{app}}\right)$ for conversion of $\mathrm{CO}_{2}$ to $\mathrm{CH}_{4}$ is given by:

$$
\alpha_{\mathrm{app}}=\left(\delta \mathrm{CO}_{2}+10^{3}\right) /\left(\delta \mathrm{CH}_{4}+10^{3}\right)
$$

where $\delta \mathrm{CO}_{2}$ and $\delta \mathrm{CH}_{4}$ are directly measured isotopic signatures of the carbon in $\mathrm{CO}_{2}$ and $\mathrm{CH}_{4}$, respectively.

Fractionation factor for hydrogenotrophic methanogenesis $\left(\alpha_{\mathrm{mc}}\right)$ is given by:

$$
\alpha_{\mathrm{mc}}=\left(\delta \mathrm{CO}_{2}+10^{3}\right) /\left(\delta_{\mathrm{mc}}+10^{3}\right)
$$

where $\delta_{\mathrm{mc}}$ is carbon isotopic signature of methane solely produced from carbon dioxide (directly measured from assays 
inhibited by methyl fluoride). Partition of hydrogenotrophic methanogenesis is calculated by the following mass balance Equation (7):

$$
f_{\mathrm{mc}}=\left(\delta_{\mathrm{CH} 4}-\delta_{\mathrm{ma}}\right) /\left(\delta_{\mathrm{mc}}-\delta_{\mathrm{ma}}\right)
$$

where $f_{m c}$ is the partition of hydrogenotrophic methanogenesis and $\delta_{\mathrm{ma}}$ is carbon isotopic signature of methane solely produced from acetate. It is calculated from the following equation:

$$
\delta_{\mathrm{ma}}=\left(1 / \alpha_{\mathrm{ma}}\right)\left(\delta_{\mathrm{ac}}+10^{3}-\alpha_{\mathrm{ma}}{ }^{*} 10^{3}\right)
$$

where $\alpha_{\mathrm{ma}}$ is fractionation factors for acetoclastic methanogenesis and $\delta_{\mathrm{ac}}$ is the measured isotopic signal of acetate. Several published $\alpha_{\text {ma }}$ have been used to estimate the contribution of hydrogenotrophic methanogenesis e.g., (Gelwicks et al., 1994; Penning et al., 2006; Goevert and Conrad, 2009).

\section{Molecular Analyses}

DNA was extracted from the fresh sediment before the start of the incubation and at the end of the incubations (with and without methyl-fluoride) using the PowerSoil DNA Isolation Kit (MO BIO, USA), according to the manufacturer's instructions. The extracted DNA was used to characterize the $m c r A$ gene by T-RFLP (Terminal-restriction length polymorphism) according to Chin et al. (Liu et al., 1997; Chin et al., 1999) using the primers $m c r A$ f (TAY GAY CAR ATH TGG YT) and $m c r A$ r (ACR TTC ATN GCR TAR TT) published by Springer et al. (1995) with a FAM (6-carboxyfluorescein)-label at the forward primer. The $m c r A$ gene amplicons were digested with Sau96I (Fermentas), and the products were size-separated in an ABI 3130 DNA sequencer (Applied Biosystems, Darmstadt, Germany). For downstream analysis only fragments between 80 and $520 \mathrm{bp}$ have been considered to avoid analysis of false signals originated from primer residuals, primer dimmers, and undigested PCR product. The normalization and standardization of the T-RFLP profiles was done according the method from Dunbar et al. (2001). The relative abundance was calculated using the ratio between the height of the fluorescence signal and the total height of all signals in one sample. To assign the resulting fragments we used a clone library which was constructed in our lab in a framework to characterize the methanogenic community at different locations and depth of River Sitka (Figure S9). The dominant peaks well-reflect published literature values of other water logged systems (Lueders et al., 2001; Ramakrishnan et al., 2001; Chin et al., 2004; Kemnitz et al., 2004; Conrad et al., 2008).

\section{Results}

All samples of core I and almost all samples of core II (except the $20-30$ and $30-40 \mathrm{~cm}$ depth and the $10-20 \mathrm{~cm}$ depth under inhibited conditions) released methane and all samples released carbon dioxide under the chosen incubation conditions (Figure 1, Figures S1, S2). Both cores showed the same vertical pattern of methane emission rates (Figure 1, Figure S1): The highest average methane production rates (up to $34 \pm 11 \mathrm{nmol}$

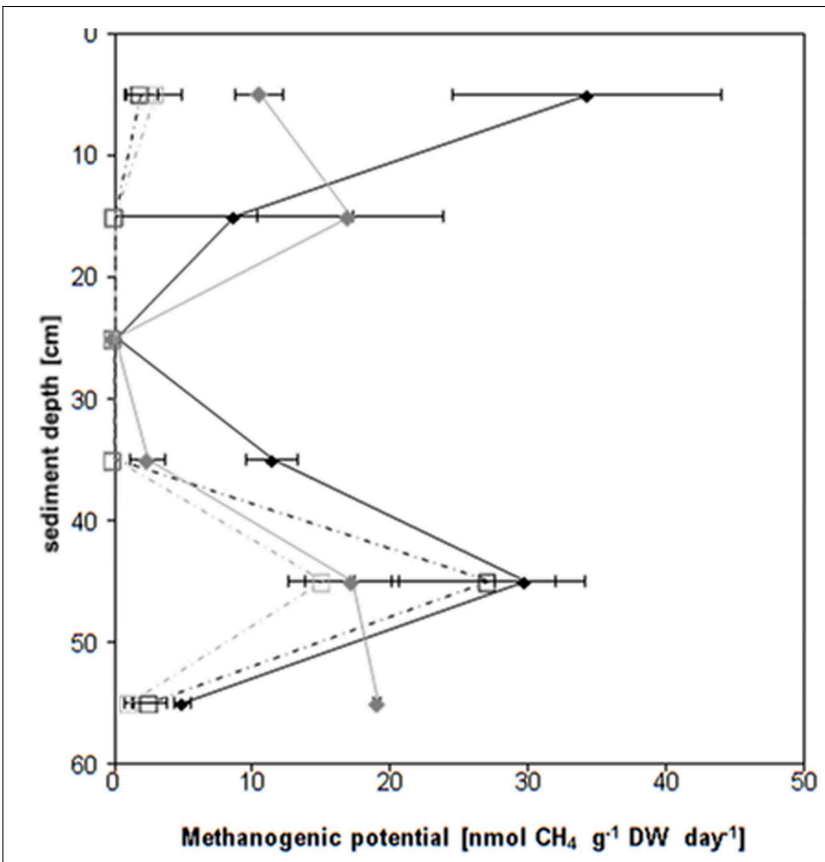

FIGURE 1 | Vertical profile $(60 \mathrm{~cm}$ depth sampled in $10 \mathrm{~cm}$ slices) of the methanogenic potential of two sediment cores. Core I uninhibited control $\mathrm{N}_{2} \downarrow$, core I methyl fluoride $\left(\mathrm{N}_{2}+3 \% \mathrm{CH}_{3} \mathrm{~F}\right) \downarrow$, core II uninhibited control $\mathrm{N}_{2} \square$, core II methyl fluoride $\left(\mathrm{N}_{2}+3 \% \mathrm{CH}_{3} \mathrm{~F}\right) \square$. The methanogenic potential (in nmol per $\mathrm{g}$ dry weight (DW) per day) has been calculated using the slope of the methane concentration over the last 10-11 day of the incubation (compare Figure S1). The values of the individual layers (e.g., $0-10 \mathrm{~cm}$ ) are given as average (e.g., $5 \mathrm{~cm}$ ) The rates are given \pm standard deviation $(n=3-5)$.

$\mathrm{CH}_{4} \mathrm{~g}^{-1} \mathrm{DW}$ day ${ }^{-1}$ ) were found in the top $10 \mathrm{~cm}$ and in the 40 $50 \mathrm{~cm}$ depth layer. The $10-40 \mathrm{~cm}$ depth layers as well as the $50-$ $60 \mathrm{~cm}$ depth layer proved low methane production rates (below $9 \pm 9 \mathrm{nmol} \mathrm{CH}_{4} \mathrm{~g}^{-1} \mathrm{DW}$ day $^{-1}$ ) for the first core and negligible if any methane production for the second core. Roughly threefold more methane was released under uninhibited conditions in the top $10 \mathrm{~cm}$; the $40-50 \mathrm{~cm}$ peak was doubled in the absence of methyl fluoride. In the presence of methyl fluoride methane production rates followed the same pattern, again showing the highest values in the $40-50 \mathrm{~cm}$ depth layer of both cores.

The concentrations of free carbon dioxide in the headspace increased in all sediment layers under all tested treatments in both cores (Figure S2). During the methanogenic lag phase carbon dioxide concentrations of both cores increased faster and later on the increase was slowing down up to the end of incubation. The upper $10 \mathrm{~cm}$ of both cores showed the highest concentrations. Generally methyl fluoride amendment did not systematically affect the carbon dioxide concentrations.

In both cores the $\delta^{13} \mathrm{C}$ of methane for uninhibited controls was in the range of -98.6 to $-48.2 \%$ and for inhibited incubations in the range of -116.3 to $-74.5 \%$ (Figure 2, Figure S3). The $\delta^{13} \mathrm{C}$ of methane was not affected by the sampling depth. The in-situ $\delta^{13} \mathrm{C}$ of methane $(-59.0 \pm 1.2 \%, n=9)$ was very close to the methane measured in the maximum methanogenic depth layers for uninhibited control assays ( -59 to $-62 \%$ ). 


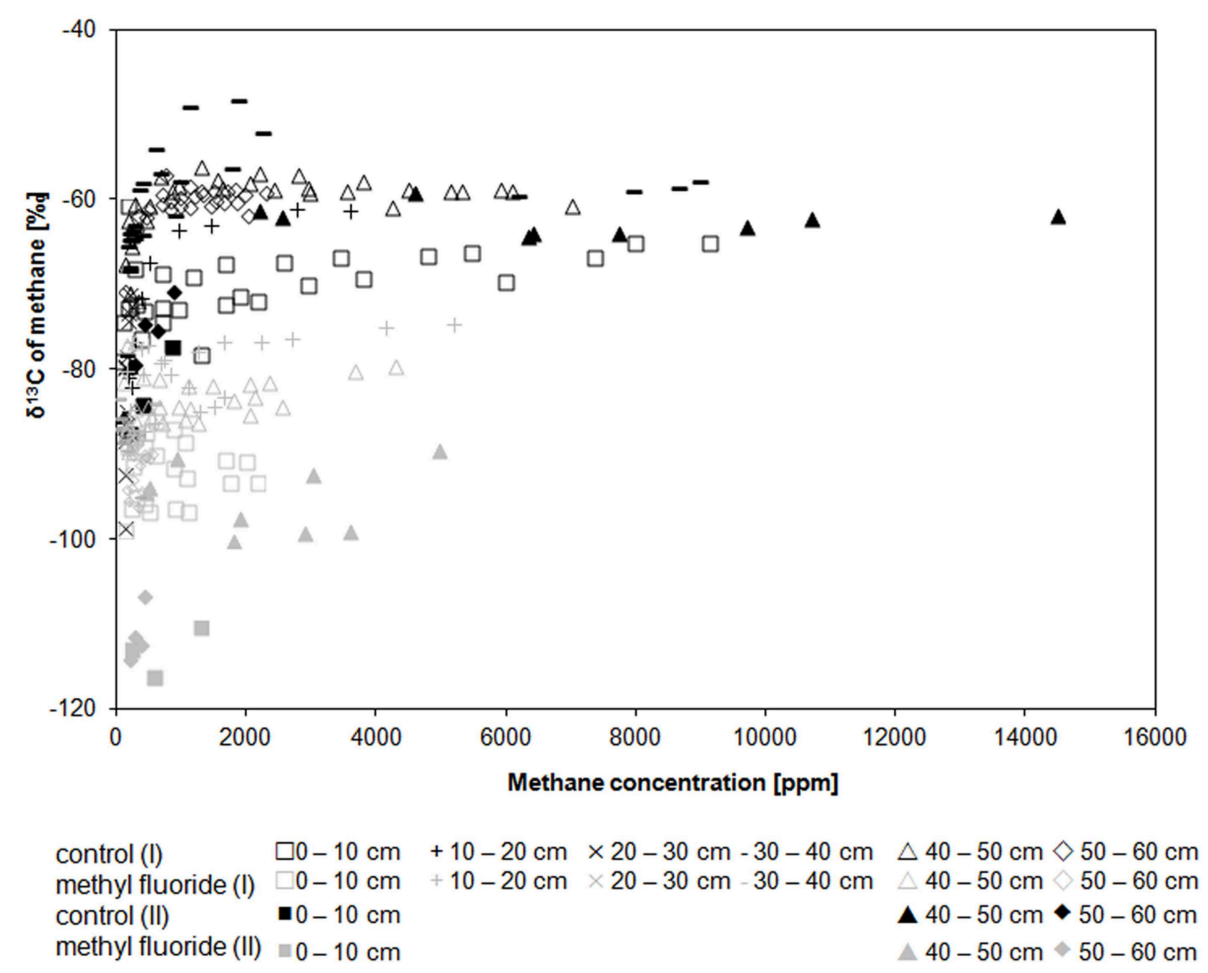

FIGURE 2 | Course of the $\delta^{13} \mathrm{C}$ of $\mathrm{CH}_{4}$ along $\mathrm{CH}_{4}$ concentrations in both inhibited and uninhibited control assays for core (I) open symbols and core (II) filled symbols.
Uninhibited control incubations $\left(\mathrm{N}_{2}\right)$ in black, methyl fluoride inhibited samples $\left(\mathrm{N}_{2}+3 \% \mathrm{CH}_{3} \mathrm{~F}\right)$ in gray. Details are likewise plotted in Figures S1, S3.
The $\delta^{13} \mathrm{C}$ of carbon dioxide was irrespective of the treatment during the incubations in the range of -18.8 to $-36.0 \%$ for all depth layers and both cores (Figure S4). The initially light $\mathrm{CO}_{2}$ ( -18.8 to $-25.3 \%$ ) usually became heavier during the incubation; only the samples showing high methane production rates had lighter $\mathrm{CO}_{2}$ in the end (Figure S4). The in-situ $\delta^{13} \mathrm{C}$ carbon dioxide was slightly heavier $(-16.3 \pm 1.2 \%, n=9)$.

We calculated the apparent fractionation $\left(\alpha_{\text {app }}\right)$ for uninhibited control and inhibited samples using Equations (5) and (6), respectively, (Figure 3). While the apparent fractionation of core I for the uninhibited samples was on average $1.046 \pm 0.009(n=54)$ ranging from $1.039(50-60 \mathrm{~cm})$ to $1.062(20-30 \mathrm{~cm})$, the inhibited samples were approximately $20 \%$ more depleted in ${ }^{13} \mathrm{C}: 1.065 \pm 0.006(n=43)$ ranging from $1.057(10-20 \mathrm{~cm})$ to $1.073(0-10 \mathrm{~cm})$. Only three depth layers $(0-10,40-50$, and $50-60 \mathrm{~cm})$ of core II could be fully evaluated using prolonged incubation times (30-80 days). The apparent fractionation of the uninhibited samples ranged from 1.039 to 1.065 . The inhibited samples again were approximately $29 \%$ more depleted in ${ }^{13} \mathrm{C}$ and ranged from 1.069 to 1.088 . It is worth noting that the two depth layers with the highest methane production potentials showed distinct apparent fractionations: in the top layer the average apparent fractionation was 1.073 in the inhibited and 1.050 in the uninhibited samples; in the $40-50 \mathrm{~cm}$ depth layer the apparent fractionation was 1.062 and 1.040 , respectively. The average apparent fractionation factor for the in situ samples was $1.045 \pm 0.002(n=9)$.

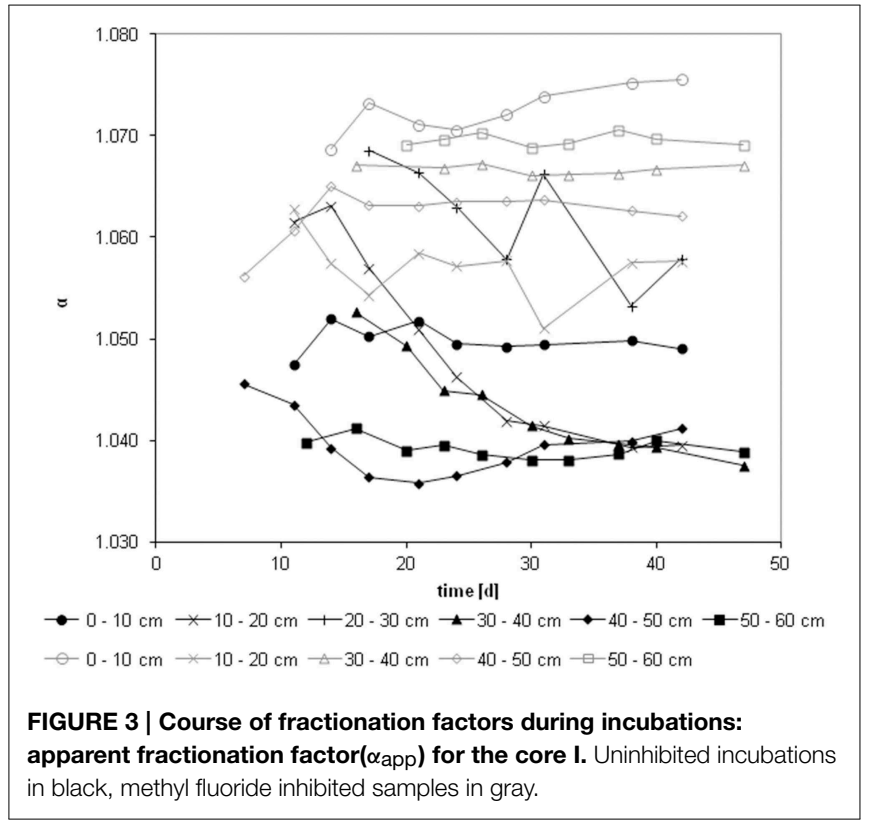

Carbon contents in incubated sediments are listed in Table 2. They showed no vertical pattern but differed in the two sediment cores. The average carbon isotope values of organic matter was $-26.3 \%$ ( $\pm 0.1 \% 0, n=12)$. The acetate concentrations at the end of the incubations stayed at a relatively low level $(<0.02 \mathrm{mM}$ 
TABLE 2 | Depth profiles of two sediment cores.

\begin{tabular}{|c|c|c|c|c|c|c|}
\hline \multirow[t]{2}{*}{ Depth [cm] } & \multirow[t]{2}{*}{$\mathrm{C}_{\text {soil }}[\%]$} & \multirow[t]{2}{*}{$\delta^{13} C_{\text {soil }}[\%]$} & \multicolumn{2}{|c|}{ Uninhibited } & \multicolumn{2}{|c|}{ methylfluoride } \\
\hline & & & acetate [mM] & $\delta^{13} C_{\text {acetate }}[\%]$ & acetate [mM] & $\delta^{13} \mathbf{C}_{\text {acetate }}[\% 0]$ \\
\hline \multicolumn{7}{|l|}{ CORE I. } \\
\hline $0-10$ & 0.6 & -26.2 & n.d. & n.d. & $1.53 \pm 0.6$ & $-42.0 \pm 1.2$ \\
\hline $10-20$ & 2.3 & -25.9 & n.d. & n.d. & $0.47 \pm 0.17$ & $-47.8 \pm 7.9$ \\
\hline $20-30$ & 0.9 & -25.8 & n.d. & n.d. & n.d. & n.d. \\
\hline $30-40$ & 2.9 & -26.8 & $0.02 \pm 0.00$ & $-27.4 \pm 1.4$ & $0.58 \pm 0.16$ & $-34.9 \pm 1.9$ \\
\hline $40-50$ & 2.3 & -26.8 & $0.03 \pm 0.00$ & $-27.8 \pm 0.2$ & $0.79 \pm 0.07$ & $-34.3 \pm 1.0$ \\
\hline $50-60$ & 1 & -26.3 & $0.02 \pm 0.00$ & $-29.6 \pm 0.4$ & $0.08 \pm 0.06$ & $-31.0 \pm 1.2$ \\
\hline \multicolumn{7}{|l|}{ CORE II. } \\
\hline $0-10$ & 0.5 & -26.4 & n.d. & n.d. & $0.31 \pm 0.41$ & $-50.7 \pm 1.0$ \\
\hline $10-20$ & 0.7 & -26.3 & n.d. & n.d. & n.d. & n.d. \\
\hline $20-30$ & 0.9 & -26.3 & n.d. & n.d. & n.d. & n.d. \\
\hline $30-40$ & 0.7 & -26 & n.d. & n.d. & n.d. & n.d. \\
\hline $40-50$ & 6.8 & -26.7 & $0.02 \pm 0.00$ & $-27.5 \pm 1.0$ & $1.16 \pm 0.27$ & $-40.7 \pm 4.9$ \\
\hline $50-60$ & 2.4 & -26.2 & n.d. & n.d. & $0.02 \pm 0.01$ & $-38.6 \pm 1.3$ \\
\hline
\end{tabular}

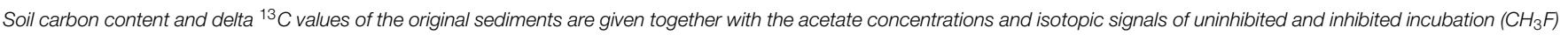
experiments at the end of the incubation. n.d. not detected. Values are given \pm standard deviation $n=3$.

uninhibited; up to $1.5 \mathrm{mM}$ under $\mathrm{CH}_{3} \mathrm{~F}$ ) again showing a peak in the top $10 \mathrm{~cm}$ and for the $40-50 \mathrm{~cm}$ depth layer. The $\delta^{13} \mathrm{C}$ values of acetate were in the range of -50.7 to $-31 \%$ and -30.8 to $-27.5 \%$ for inhibited and uninhibited incubation assays respectively, (Table 2). For all sediment samples, the $\delta^{13} \mathrm{C}$ of produced acetate was lower than the $\delta^{13} \mathrm{C}$ of organic matter. Other parameters (e.g., $\mathrm{H}$ and $\mathrm{N}$ content) are listed in Table S1.

The contribution of hydrogenotrophic methanogenesis $\left(f_{\mathrm{mc}}\right)$ was calculated by Equation (7) incorporating measured $\delta^{13} \mathrm{C}$ of methane $\left(\delta_{\mathrm{CH} 4}\right)$, methane produced purely from hydrogenotrophic methanogenesis $\left(\delta_{\mathrm{mc}}\right)$ and an estimate for the methane produced from acetate $\left(\delta_{\mathrm{ma}}\right)$ based on measured ${ }^{13} \mathrm{C}$ acetate and fractionation factors of acetoclastic methanogenesis presented in literature. The time courses of $f_{m c}$ in the core (I) calculated with $\alpha_{\mathrm{ma}}=1.009$ (Goevert and Conrad, 2009) is shown in Figure 4. In the beginning almost all methane was produced from hydrogen; later the contribution of hydrogenotrophic methanogenesis dropped to about $40 \%$. In core II only three depth layers could be evaluated during the second half of the incubation period. These samples showed a contribution of $26-45 \%$ of hydrogenotrophic methanogenesis to the released methane.

The molecular analysis of the methanogenic marker-gene ( $m c r A)$ revealed a significant different methanogenic community for the top layer in contrast to deeper layers (Figure 5). The community profile (T-RFLP of $m c r A$ ) resolves in up to 11 fragments (Figure S8). The microbial community was not affected by the incubation under $\mathrm{N}_{2}$ or $\mathrm{N}_{2}+\mathrm{CH}_{3} \mathrm{~F}$. In all depth layers and under all incubation conditions Methanosarcinacea were the dominant group (22-52\%) followed by Methanobacteriacea (24-56\%); Methanomicrobiales were only detectable in the two active layers (up to 12\%). Methanosaetacea were almost absent in the top layer (below 3\%) and reached a higher relative abundance in deeper layers (10-25\%). The samples of core II have not been analyzed by T-RFLP. However, a core sampled in 2014 at the same location did confirm the overall pattern of the T-RFLP but showed a more gradual change of the community over the depth profile.

\section{Discussion}

\section{Methane Production Potentials in River Sediments}

Estimations of the methane production potentials of river sediments have so far only been made for mixed top sediments: e.g., White Oak River sediment incubations at $25^{\circ} \mathrm{C}$ had methane production potentials of approximately $250 \mathrm{nmol} \mathrm{gDW}^{-1} \mathrm{~d}^{-1}$ (originally given as $8 \mu \mathrm{M} \mathrm{hr}^{-1}$ ) (Avery and Martens, 1999). Incubations of fresh top sediment layers or river Sitka sampled in spring 2014 and incubated under similar conditions as reported in this study resulted in more than tenfold larger methane production potentials of $469 \mathrm{nmol} \mathrm{gDW}^{-1} \mathrm{~d}^{-1}$ (Bednarik unpublished) compared to $34 \mathrm{nmol} \mathrm{CH}_{4} \mathrm{gDW}^{-1} \mathrm{~d}^{-1}$ reported for the top $10 \mathrm{~cm}$ in this study. While top sediments of the Elbe River had maximum potential methane production rates of $552 \mathrm{nmol} \mathrm{gDW}^{-1} \mathrm{~d}^{-1}$ (Matoušu in preparation). This would suggest that the methane production potential of river sediments

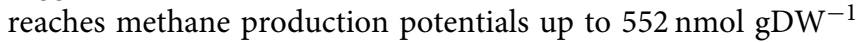
$\mathrm{d}^{-1}$. For comparison lake sediments have a methane production potential of e.g., 9-3380 $\mathrm{nmol} \mathrm{gDW}^{-1} \mathrm{~d}^{-1}$ (Conrad et al., 2010, 2011) while rice field soils show methane production rates of 3360-7920 $\mathrm{nmol} \mathrm{gDW}^{-1} \mathrm{~d}^{-1}$ (Conrad et al., 2009a, 2012).

In order to better understand the methanogenic potential of river sediments we incubated several depth layers of two sediment cores under anoxic conditions in the laboratory. While published data of in situ measurement of methane concentrations in river sediments pointed to diverse vertical profiles, reaching 
several hundred $\mu \mathrm{M}$ (Table 3) it is as well-possible that the in situ concentrations are independent from the underlying methane production potential.

Indeed we find two distinctive peaks of methane production in the present study (up to $34 \mathrm{nmol}_{\mathrm{gDW}}^{-1} \mathrm{~d}^{-1}$ ) which correlated with higher $\mathrm{CO}_{2}$ production in these layers and acetate accumulation in the inhibited samples. These peaks are present

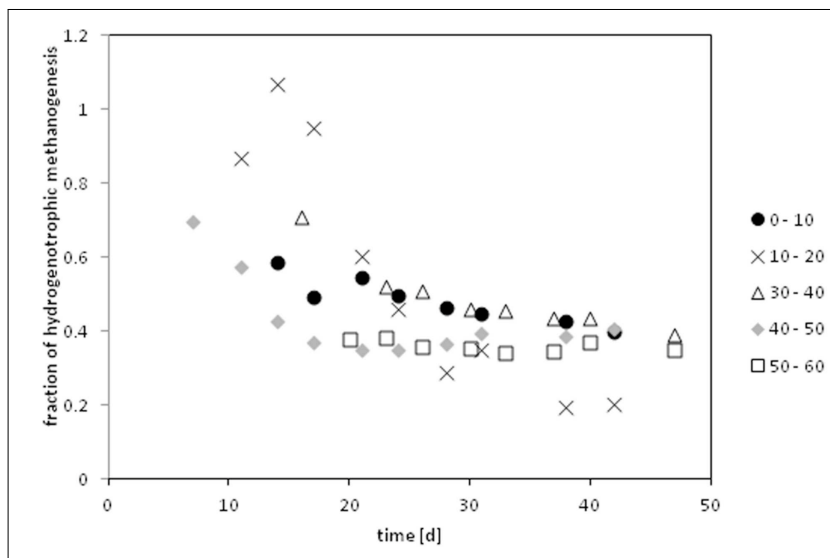

FIGURE 4 | Relative contribution of hydrogenotrophic methanogenensis to the released methane of the depth profile of core I. Calculated assuming a fractionation factor of $\alpha_{\text {app }}=1.009$ for acetoclastically produced methane. (Compare Figures S5, S6). The $20-30 \mathrm{~cm}$ depth did not release methane under inhibited conditions; hence the contribution of hydrogenotrophic methanogens could not be calculated for that sample. in both cores which have been separately analyzed. The earlier reported preliminary methane production potentials for River Sitka under substrate addition (ca. $8 \mu \mathrm{M}$ acetate) were much lower (below $6 \mathrm{nmol} \mathrm{gDW}^{-1} \mathrm{~d}^{-1}$ ) and only based on two time points and a very short incubation time $(72 \mathrm{~h}$ ) (Rulik et al., 2013). Since we could show that roughly $40 \%$ of methane is produced hydrogenotrophically, these short time incubations under substrate addition may not reflect the natural conditions. However, already these incubations showed two distinct peaks for the top sediment and $40-50 \mathrm{~cm}$ depth. In this respect it is worth to note that the lag phase of our incubation experiments lasted for about 15-35 days (Figure S1), which is most probable due to the presence of other electron acceptors which have to be depleted before methanogenesis starts.

The methane production potential of the top layer is paralleled by high oxygen saturation ( $>80 \%$ ) (Rulik et al., 2013), low in situ methane concentrations (Table 3) and high activities of methanotrophic bacteria [Figure S7 and (Rulik et al., 2013)]. The second peak goes along with lower oxygen saturation (17.5\%) (Rulik et al., 2013), intermediate in situ methane concentration, and reduced methanogenic activity. However, it is presently not clear why the intermediate zone $(10-30 \mathrm{~cm})$ shows almost no methanogenic potential.

\section{Methanogenic Pathways in River Sediments}

Our result shows that carbon isotopic values of methane measured both in situ $(-59 \%)$ and in different incubations of depth layers $\left(-68\right.$ to $-59 \%$ ) were in the broad range of $\delta^{13} \mathrm{C}$ of methane measured in other studies in rivers e.g., in situ measurements from the Amazonian rivers ranged from -75

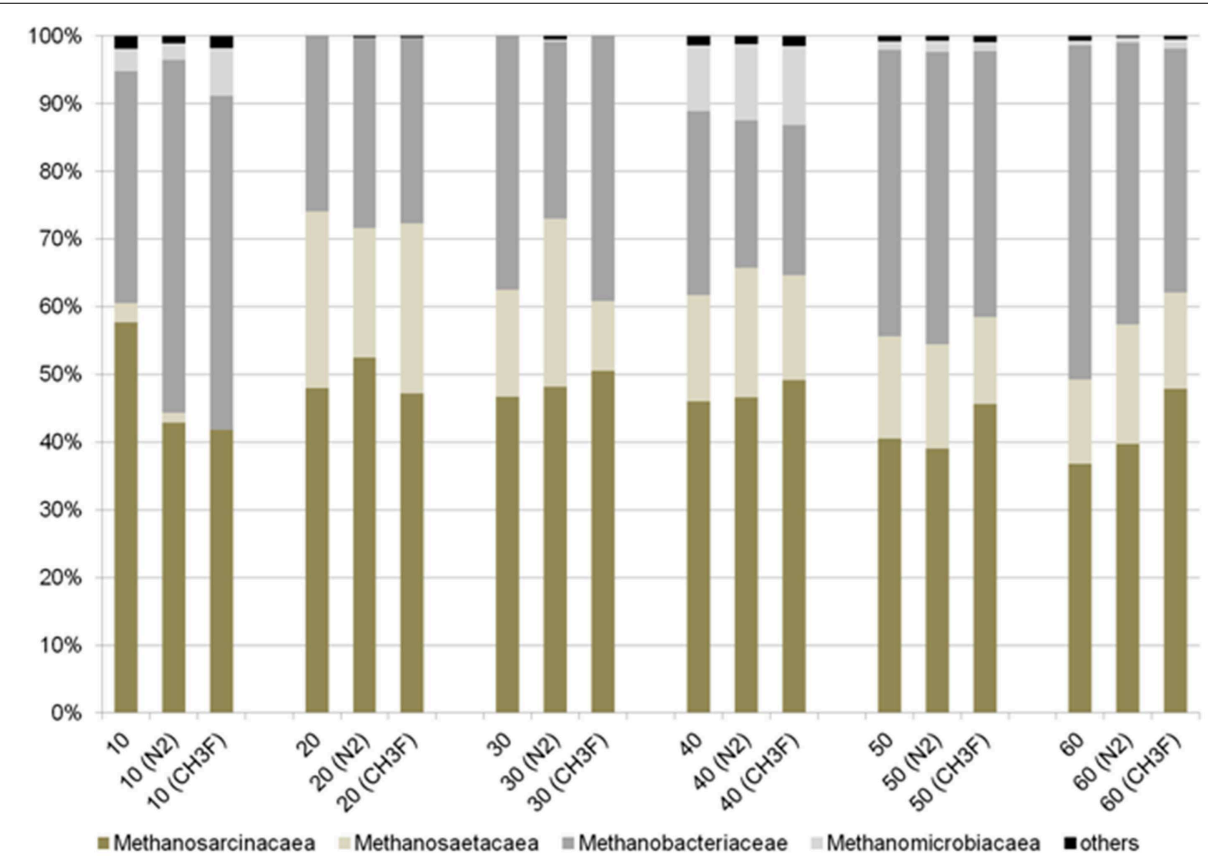

FIGURE 5 | Relative abundance of important methanogenic groups as determined by T-RFLP for core I (different depth layers up to $60 \mathrm{~cm}$ depth). Results are given for samples before the incubation as well as at the end of incubations under $\mathrm{N}_{2}$ (control incubations) or $\mathrm{N}_{2}+2 \% \mathrm{CH}_{3} \mathrm{~F}$ (inhibition of acetoclastic methanogenesis). Details on T-RFLP results are given in Figure S8. 
TABLE 3 | Methane concentration in depth profiles of river sediments.

\begin{tabular}{|c|c|c|c|c|}
\hline River & Sample description & Depth (cm) & $\mathrm{CH}_{4}$ concentration $(\mu \mathrm{M})$ & References \\
\hline \multirow[t]{3}{*}{ Hudson } & Station 118 Aug. 23, 1991 & 50 & 0.105 & $\begin{array}{l}\text { De Angelis and } \\
\text { Scranton, } 1993\end{array}$ \\
\hline & & 1000 & 0.99 & $\begin{array}{l}\text { De Angelis and } \\
\text { Scranton, } 1993\end{array}$ \\
\hline & & 2000 & 0.108 & $\begin{array}{l}\text { De Angelis and } \\
\text { Scranton, } 1993\end{array}$ \\
\hline Severnaya Dvina River & Station 20 & $0-5$ & 0.5 & Gar'Kusha et al., 2010 \\
\hline (White Sea) & & $5-10$ & 3 & Gar'Kusha et al., 2010 \\
\hline Allequash Creek & Lower site & 20 & 430 & $\begin{array}{l}\text { Schindler and } \\
\text { Krabbenhoft, } 1998\end{array}$ \\
\hline \multirow[t]{3}{*}{ (Wisconsin, USA) } & & 60 & 410 & $\begin{array}{l}\text { Schindler and } \\
\text { Krabbenhoft, } 1998\end{array}$ \\
\hline & & 180 & 400 & $\begin{array}{l}\text { Schindler and } \\
\text { Krabbenhoft, } 1998\end{array}$ \\
\hline & Upper site & top & 2 & $\begin{array}{l}\text { Schindler and } \\
\text { Krabbenhoft, } 1998\end{array}$ \\
\hline \multirow[t]{3}{*}{ Jiulong River Estuarine } & & 90 & 6 & Chen and Yin, 2013 \\
\hline & & $100-140$ & $2-3$ & Chen and Yin, 2013 \\
\hline & & 150 & 6 & Chen and Yin, 2013 \\
\hline \multirow[t]{5}{*}{ Sitka } & Location IV & 10 & 20 & Rulik et al., 2013 \\
\hline & & 20 & 175 & Rulik et al., 2013 \\
\hline & & 30 & 300 & Rulik et al., 2013 \\
\hline & & 40 & 175 & Rulik et al., 2013 \\
\hline & & 50 & 260 & Rulik et al., 2013 \\
\hline
\end{tabular}

to $-53 \%$ (Moura et al., 2008) but slightly heavier than methane collected from interstitial water at $40-50 \mathrm{~cm}$ depth in Sitka $(-72$ to $-68 \%$ ) (Rulik et al., 2013).

Assuming complete inhibition of acetoclastic methanogenesis in the presence of methyl fluoride $\left(\mathrm{CH}_{3} \mathrm{~F}\right)$ the isotopic signal of the methane can be completely attributed to hydrogenotrophically produced $\mathrm{CH}_{4}\left(\delta_{m c}\right)$. The range for the apparent fractionation reported in our study $\left(\alpha_{\mathrm{app}}=1.04\right.$ to 1.06) have quite commonly been observed in e.g., rice field soils (Sugimoto and Wada, 1993; Chidthaisong et al., 2002; Penning and Conrad, 2007; Conrad et al., 2009b).

The fractionation factor $\left(\alpha_{\mathrm{ma}}\right)$ during conversion of total acetate to methane in Methanosarcina acetivorans and $M$. barkeri ranges from $\alpha_{\mathrm{ma}}$ of 1.012-1.027 (Gelwicks et al., 1994; Conrad, 2009; Goevert and Conrad, 2009), whereas isotope fractionation in Methanosaeta spp. is weaker, i.e., $\alpha_{\mathrm{ma}}$ of 1.0071.009 (Valentine et al., 2004; Penning et al., 2006). From an earlier study, it was found that both acetoclastic genera Methanosarcina spp. and Methanosaeta spp. occur in Sitka sediments (Buriankova et al., 2013). Therefore, we calculated the contribution of hydrogenotrophic methanogenesis with all published fractionation factors ranging up to $\alpha_{\mathrm{ma}}=1.027$ (Figure S5). However, $\alpha_{\mathrm{ma}}=1.009$ is maybe most reasonable because fractionation factors of acetoclastic methanogenesis under environmental settings are approximately 5-10\%o less negative than in pure culture, which is probably due to limitation by acetate (Penning and Conrad, 2007; Conrad, 2009; Goevert and Conrad, 2009). We used the isotopic value of the total acetate for our calculations, which may be incorrect since we find a high contribution of acetogenesis to the acetate pool (compare Discussion below). If we use the isotopic signal of the soil organic carbon as a proxy for the acetate values we get almost the same results (Figure S6 and accompanying discussion). When carbohydrates are methanogenically degraded $f_{\mathrm{mc}}$ is expected to be $33 \%$, which is commonly observed in e.g., rice field soils (Conrad, 1999). Other environments like e.g., lake sediments can have much larger contributions of hydrogenotrophically produced methane (Conrad, 1999). Estimates of $f_{m c}$ for White Oak River sediments were reported to be 37-39\% (Avery and Martens, 1999) which is in good agreement with our own results (40\%). Comparing the different layers of our depth profile it was found that the upper maximum $(0-10 \mathrm{~cm})$ produce slightly more hydrogenotrophic methane $42-51 \%$ than the $40-50 \mathrm{~cm}$ layer $36-46 \%$.

\section{Isotope Fractionation during Acetate Production}

While the major sink of acetate in methanogenic environments is methane two dominant mechanisms are known to replenish the acetate pool: Acetate is produced either by fermentation of organic matter or by reduction of $\mathrm{CO}_{2}$ with $\mathrm{H}_{2}$ via the acetyl-CoA pathway (acetogenesis) (Drake et al., 2006). Hence the in-situ $\delta^{13} \mathrm{C}$ value of acetate is influenced by all three reactions (Heuer et al., 2010; Conrad et al., 2014). Acetoclastic methanogenesis has a moderate fractionation around $\alpha=1.01$ (see Discussion above), fermentation has only a very weak preference for either carbon isotope $[\alpha<1.009$ (Blair et al., 1985; Penning and 
Conrad, 2006)], a stronger preference for light carbon has been determined for the acetyl-CoA pathway $[\alpha=1.06$ (Gelwicks et al., 1989; Blaser et al., 2013)]. In principle syntrophic acetate oxidation coupled to hydrogenotrophic methanogenesis is an alternative route to deplete acetate (Zinder and Koch, 1984; Conrad and Klose, 2011; Rui et al., 2011; Dolfing, 2014).

As a result of all three reactions the acetate signatures in environmental samples are usually in the range of the soil organic carbon $( \pm 10 \%$ ) e.g., (Conrad et al., 2011, 2014). The presence of methyl fluoride blocks the only acetate depleting reaction (in our experimental set up) and hence results in an accumulation of acetate. In most studies this acetate however does no significantly differ from the acetate signature of the uninhibited control incubations under $\mathrm{N}_{2}$ e.g., (Heuer et al., 2010; Conrad et al., 2011). In our sample the acetate signatures of the uninhibited samples are similar to the ${ }^{13} \mathrm{C}$ values of soil organic carbon, while inhibited samples are always depleted in ${ }^{13} \mathrm{C}$ relative to the soil organic carbon $(-5$ to $-24 \%$; compare Table 1). This may point to a relative high contribution of the strong fractionating acetyl-CoA pathway to the acetate signature under these conditions.

If we assume complete inhibition of acetoclastic methanogenesis in these samples and no fractionation during fermentation, the contribution of the acetyl-CoA pathway can be calculated to be $8-41 \%$ (Table S2). If a stronger fractionation during fermentation $(\alpha=1.01)$ is assumed the contribution is between 0 and $29 \%$. In comparison we calculated a lower contribution of acetogenic bacteria for data published by Conrad et al. (2011) on anoxic lake sediments: $0-19 \%$ (no fractionation scenario) or $0-3 \%(\alpha=1.01)$.

Under methyl fluoride inhibition the acetyl-CoA pathway competes with hydrogenotrophic methanogenesis for the substrates hydrogen and carbon dioxide which are either reduced to acetate or to methane. Since methanogenesis is energetically more favorable than acetogenesis (131 vs. $95 \mathrm{~kJ} \mathrm{~mol}^{-1}$ ) it outcompetes acetogenesis in many environments (Kotsyurbenko et al., 2001). Acetogenesis can become dominating under elevated hydrogen partial pressures: e.g., Heuer et al. reported strongly depleted acetate $\left(\delta_{\text {acetate }}=-48.8 \%\right.$ for lake sediments incubated under elevated hydrogen partial pressure (Heuer et al., 2010). Likewise low temperatures favor the prevalence of acetogens over hydrogenotrophic methanogens (Kotsyurbenko et al., 2001). Oxygen is a third factor in favor of acetogenic bacteria which are better adopted to aerated environments than methanogens (Kuesel and Drake, 1995).

Our data suggest that acetogenic bacteria contribute up to $40 \%$ of the produced acetate in river sediments (under $\mathrm{CH}_{3} \mathrm{~F}$ inhibition) and that they can effectively compete with hydrogenotrophic methanogens. Therefore, acetogens may play an important yet not well-characterized role in river sediment ecology.

\section{Methanogenic Community Profile}

The methanogenic community based on T-RFLP of $m c r A$ has so far primarily been described for rice field soils (Lueders et al., 2001; Ramakrishnan et al., 2001; Chin et al., 2004; Kemnitz et al., 2004; Conrad et al., 2008). Most of the fragments we found in the clone library of river systems were identical with previously published T-RF's. The only exception was the 473 bp fragment, which is distinct from the $470 \mathrm{bp}$ fragment of Methanobacteria (Lueders et al., 2001; Chin et al., 2004) and could be assigned to the order of Methanomicobiales using cloning and sequencing (Figure S9). This fragment was only present in the two layers showing high methanogenic potentials. The absence of Methanosaetacea in the top layer is plausible since they are commonly found in permanent anoxic systems like fresh water sediments (Banning et al., 2005; Chan et al., 2005; Youngblut et al., 2014) but only dominate in rice paddies when acetate is scarce (Lueders et al., 2001; Ramakrishnan et al., 2001; Chin et al., 2004; Kemnitz et al., 2004; Conrad et al., 2008). This has been attributed to a reduced stress tolerance of these strains e.g., lower oxygen tolerance (Erkel et al., 2006; Yuan et al., 2011). Molecular data based on the $m c r A$ gene suggest that the methanogenic community is stable over the depth (ca. $10^{7}$ $m c r A$ copies $\mathrm{g}^{-1} \mathrm{DW}$, Chaudhary et al., in preparation). Likewise the pathway usage (compare Discussion above) is only mildly affected by the sediment depth. It is therefore most plausible that the differences in the methane production potential are caused by the activity of different methanogenic archaea and may as well be influenced by substrate availability. Indeed the $40-50 \mathrm{~cm}$ depth peak has the highest organic carbon content in core II (compare Table 2).

Our study revealed no difference in the T-RFLP profiles before and after incubations suggesting that the methanogenic community was rather stable over the approximately 2 month incubation period. Similar results have been found for rice field soil incubations (Yuan et al., 2011; Ma et al., 2012) and river sediment (Beckmann and Manefield, 2014). It can therefore be assumed that the differences in the methanogenic potential are regulated on the RNA or activity level of $m c r A$ rather than caused by growth of the methanogenic archaea. This would also explain why the second methanogenic peak in the potential measurements $(40-50 \mathrm{~cm})$ could not be anticipated by the molecular data alone. The presence of methyl fluoride did not impact the T-RFLP profiles. This is in agreement with Daebeler et al. which showed that the presence of methylfluoride impacts the methanogenic activity rather than changing the community composition of methanogenic archaea (Daebeler et al., 2013).

\section{Conclusions}

Our experiments show that methane is produced in anoxic incubations of river sediment cores. Methane production is vertically organized showing two distinct maxima in the top layers and in $40-50 \mathrm{~cm}$ depth. The magnitude of the calculated methane production rates in rivers covers a broad range but is on average lower than the reported potential of other water logged systems (lakes, rice paddies). Likewise, the pathway usage (contribution of hydrogenotrophic methanogenesis) is comparable to previously studied fresh water systems. Under methyl fluoride inhibition the ${ }^{13} \mathrm{C}$ value of acetate is unusually light pointing to a high contribution of acetogenic bacteria. The methanogenic community composition was different in the top 
sediment while the lower segments share similar methanogenic fingerprints.

\section{Acknowledgments}

This study was supported by the Czech Grant Agency grant 526/09/1639, the European Social Fund and state budget of the Czech Republic. This work is a part of the POSTUP II project CZ.1.07/2.3.00/30.0041,

\section{References}

Angel, R., Claus, P., and Conrad, R. (2012). Methanogenic archaea are globally ubiquitous in aerated soils and become active under wet anoxic conditions. ISME J. 6, 847-862. doi: 10.1038/ismej.2011.141

Avery, G. B., and Martens, C. S. (1999). Controls on the stable carbon isotopic composition of biogenic methane produced in a tidal freshwater estaurine sediment. Geochim. Cosmochim. Acta 63, 1075-1082. doi: 10.1016/S00167037(98)00315-9

Banning, N., Brock, F., Fry, J. C., Parkes, R. J., Hornibrook, E. R. C., and Weightman, A. J. (2005). Investigation of the methanogen population structure and activity in a brackish lake sediment. Environ. Microbiol. 7, 947-960. doi: 10.1111/j.1462-2920.2004.00766.x

Bastviken, D., Tranvik, L. J., Downing, J. A., Crill, P. M., and Enrich-Prast, A. (2011). Freshwater methane emissions offset the continental carbon sink. Science 331, 50-50. doi: 10.1126/science. 1196808

Beckmann, S., and Manefield, M. (2014). Acetoclastic methane formation from Eucalyptus detritus in pristine hydrocarbon-rich river sediments by Methanosarcinales. FEMS Microbiol. Ecol. 90, 587-598. doi: 10.1111/15746941.12418

Berger, U., and Heyer, J. (1989). The methane cycle in the Saale River. J. Basic Microbiol. 29, 195-213. doi: 10.1002/jobm.3620290402

Blair, N., Leu, A., Munoz, E., Olsen, J., Kwong, E., and Des Marais, D. J. (1985). Carbon isotopic fractionation in heterotrophic microbial-metabolism. Appl. Environ. Microbiol. 50, 996-1001.

Blaser, M. B., Dreisbach, L. K., and Conrad, R. (2013). Carbon isotope fractionation of 11 acetogenic strains grown on $\mathrm{H}_{2}$ and $\mathrm{CO}_{2}$. Appl. Environ. Microbiol. 79, 1787-1794. doi: 10.1128/AEM.03203-12

Brand, W. A. (1996). High precision isotope ratio monitoring techniques in mass spectrometry. J. Mass Spectrom. 31, 225-235. doi: 10.1002/(Sici)10969888(199603)31:3<225::Aid-Jms319>3.0.Co;2-L

Bretschko, G., and Klemens, W. E. (1986). Quantitative methods and aspects in the study of the interstitial fauna of running waters. Stygologia 2, 297-316. doi: 10.1371/journal.pone.0080804

Buriankova, I., Brablcova, L., Mach, V., Dvorak, P., Chaudhary, P. P., and Rulik, M. (2013). Identification of methanogenic archaea in the hyporheic sediment of Sitka Stream. PLoS ONE 8:e80804. doi: 10.1371/journal.pone. 0080804

Buriankova, I., Brablcova, L., Mach, V., Hyblova, A., Badurova, P., Cupalova, J., et al. (2012). Methanogens and methanotrophs distribution in the hyporheic sediments of a small lowland stream. Fund. Appl. Limnol. 181, 87-102. doi: 10.1127/1863-9135/2012/0283

Chan, O. C., Claus, P., Casper, P., Ulrich, A., Lueders, T., and Conrad, R. (2005). Vertical distribution of structure and function of the methanogenic archaeal community in Lake Dagow sediment. Environ. Microbiol. 7, 1139-1149. doi: 10.1111/j.1462-2920.2005.00790.x

Chen, J. Q., and Yin, X. J. (2013). Stratified communities of methanogens in the Jiulong River estuarine sediments, Southern China. Indian J. Microbiol. 53, 432-437. doi: 10.1007/s12088-013-0397-9

Chidthaisong, A., Chin, K. J., Valentine, D. L., and Tyler, S. C. (2002). A comparison of isotope fractionation of carbon and hydrogen from paddy field rice roots and soil bacterial enrichments during $\mathrm{CO}_{2} / \mathrm{H}_{2}$ methanogenesis. Geochim. Cosmochim. Acta 66, 983-995. doi: 10.1016/S0016-7037(01) 00812-2 which is mutually financed by the previously stated funding agencies. We thank Ralf Conrad for helpful discussion.

\section{Supplementary Material}

The Supplementary Material for this article can be found online at: http://journal.frontiersin.org/article/10.3389/fmicb. 2015.00506/abstract

Chin, K. J., Lueders, T., Friedrich, M. W., Klose, M., and Conrad, R. (2004). Archaeal community structure and pathway of methane formation on rice roots. Microb. Ecol. 47, 59-67. doi: 10.1007/s00248-003-2014-7

Chin, K. J., Lukow, T., and Conrad, R. (1999). Effect of temperature on structure and function of the methanogenic archaeal community in an anoxic rice field soil. Appl. Environ. Microbiol. 65, 2341-2349.

Ciais, P. C., Sabine, G., Bala, L., Bopp, V., Brovkin, J., Thornton, P., et al. (2014) "Carbon and other biogeochemical cycles," in IPCC, 2013: Climate Change 2013: The Physical Science Basis. Contribution of Working Group I to the Fifth Assessment Report of the Intergovernmental Panel on Climate Change, eds T. F. Stocker, D. Qin, G.-K. Plattner, M. Tignor, S. K. Allen, J. Boschung, A. Nauels, Y. Xia, V. Bex, and P. M. Midgley (Cambridge; New York, NY: Cambridge University Press), 465-570.

Conrad, R. (1999). Contribution of hydrogen to methane production and control of hydrogen concentrations in methanogenic soils and sediments. FEMS Microbiol. Ecol. 28, 193-202. doi: 10.1111/j.1574-6941.1999.tb00575.x

Conrad, R. (2005). Quantification of methanogenic pathways using stable carbon isotopic signatures: a review and a proposal. Org. Geochem. 36, 739-752. doi: 10.1016/j.orggeochem.2004.09.006

Conrad, R. (2009). The global methane cycle: recent advances in understanding the microbial processes involved. Environ. Microbiol. Rep. 1, 285-292. doi: 10.1111/j.1758-2229.2009.00038.x

Conrad, R., Claus, P., and Casper, P. (2010). Stable isotope fractionation during the methanogenic degradation of organic matter in the sediment of an acidic bog lake, Lake Grosse Fuchskuhle. Limnol. Oceanogr. 55, 1932-1942. doi: 10.4319/lo.2010.55.5.1932

Conrad, R., Claus, P., Chidthaisong, A., Lu, Y., Fernandez Scavino, A., Liu, Y., et al. (2014). Stable carbon isotope biogeochemistry of propionate and acetate in methanogenic soils and lake sediments. Org. Geochem. 73, 1-7. doi: 10.1016/j.orggeochem.2014.03.010

Conrad, R., and Klose, M. (1999). How specific is the inhibition by methyl fluoride of acetoclastic methanogenesis in anoxic rice field soil? FEMS Microbiol. Ecol. 30, 47-56. doi: 10.1111/j.1574-6941.1999.tb00634.x

Conrad, R., and Klose, M. (2011). Stable carbon isotope discrimination in rice field soil during acetate turnover by syntrophic acetate oxidation or acetoclastic methanogenesis. Geochim. Cosmochim. Acta 75, 1531-1539. doi: 10.1016/j.gca.2010.12.019

Conrad, R., Klose, M., Claus, P., and Dan, J. (2009a). Activity and composition of the methanogenic archaeal community in soil vegetated with wild versus cultivated rice. Soil Biol. Biochem. 41, 1390-1395. doi: 10.1016/j.soilbio.2009.03.013

Conrad, R., Klose, M., Lu, Y., and Chidthaisong, A. (2012). Methanogenic pathway and archaeal communities in three different anoxic soils amended with rice straw and maize straw. Front. Microbiol. 3:4. doi: 10.3389/fmicb.2012.00004

Conrad, R., Klose, M., and Noll, M. (2009b). Functional and structural response of the methanogenic microbial community in rice field soil to temperature change. Environ. Microbiol. 11, 1844-1853. doi: 10.1111/j.1462-2920.2009.01909.x

Conrad, R., Klose, M., Noll, M., Kemnitz, D., and Bodelier, P. L. E. (2008). Soil type links microbial colonization of rice roots to methane emission. Glob. Change Biol. 14, 657-669. doi: 10.1111/j.1365-2486.2007.01516.x

Conrad, R., Noll, M., Claus, P., Klose, M., Bastos, W., and Enrich-Prast, A. (2011). Stable carbon isotope discrimination and microbiology of methane formation in tropical anoxic lake sediments. Biogeosciences 8, 795-814. doi: $10.5194 /$ bg-8-795-2011 
Crawford, J. T., Striegl, R. G., Wickland, K. P., Dornblaser, M. M., and Stanley, E. H. (2013). Emissions of carbon dioxide and methane from a headwater stream network of interior Alaska. J. Geophys. Res. Biogeosci. 118, 482-494. doi: 10.1002/jgrg.20034

Daebeler, A., Gansen, M., and Frenzel, P. (2013). Methyl fluoride affects methanogenesis rather than community composition of methanogenic archaea in a rice field soil. PLoS ONE 8:e53656. doi: 10.1371/journal.pone.0053656

De Angelis, M. A., and Scranton, M. I. (1993). Fate of methane in the Hudson River and Estuary. Global Biogeochem. Cycles 7, 509-523. doi: 10.1029/93GB01636

Dolfing, J. (2014). Thermodynamic constraints on syntrophic acetate oxidation. Appl. Environ. Microbiol. 80, 1539-1541. doi: 10.1128/AEM.03312-13

Drake, H. L., Küsel, K., and Matthies, C. (2006). “Acetogenic prokaryotes," in The Prokaryotes; An Evolving Electronic Resource for Microbial Cummunity, 3rd Edn., eds M. Dworkin, S. Falkow, E. Rosenberg, K.-H. Schleifer, and E. Stackebrandt (Berlin; Heidelberg: Springer-Verlag), 354-420.

Dunbar, J., Ticknor, L. O., and Kuske, C. R. (2001). Phylogenetic specificity and reproducibility and new method for analysis of terminal restriction fragment profiles of 16S rRNA genes from bacterial communities. Appl. Environ. Microbiol. 67, 190-197. doi: 10.1128/AEM.67.1.190-197.2001

Erkel, C., Kube, M., Reinhardt, R., and Liesack, W. (2006). Genome of Rice Cluster I archaea-the key methane producers in the rice rhizosphere. Science 313, 370-372. doi: 10.1126/science.1127062

Gar'Kusha, D. N., Fedorov, Y. A., and Khromov, M. I. (2010). Methane in the water and bottom sediments of the mouth area of the Severnaya Dvina River (White Sea). Oceanology 50, 498-512. doi: 10.1134/S0001437010040065

Gelwicks, J. T., Risatti, J. B., and Hayes, J. M. (1989). Carbon isotope effects associated with autotrophic acetogenesis. Org. Geochem. 14, 441-446. doi: 10.1016/0146-6380(89)90009-0

Gelwicks, J. T., Risatti, J. B., and Hayes, J. M. (1994). Carbon isotope effects associated with aceticlastic methanogenesis. Appl. Environ. Microbiol. 60, 467-472.

Goevert, D., and Conrad, R. (2009). Effect of substrate concentration on carbon isotope fractionation during acetoclastic methanogenesis by Methanosarcina barkeri and M. acetivorans and in rice field soil. Appl. Environ. Microbiol. 75, 2605-2612. doi: 10.1128/AEM.02680-08

Hayes, J. M. (1993). Factors controlling C-13 contents of sedimentary organiccompounds - principles and evidence. Mar. Geol. 113, 111-125. doi: 10.1016/0025-3227(93)90153-M

Heuer, V. B., Krueger, M., Elvert, M., and Hinrichs, K. U. (2010). Experimental studies on the stable carbon isotope biogeochemistry of acetate in lake sediments. Org. Geochem. 41, 22-30. doi: 10.1016/j.orggeochem.2009.07.004

Hlavacova, E., Rulik, M., and Cap, L. (2005). Anaerobic microbial metabolism in hyporheic sediment of a gravel bar in a small lowland stream. River Res. Appl. 21, 1003-1011. doi: 10.1002/rra.866

Hlavacova, E., Rulik, M., Cap, L., and Mach, V. (2006). Greenhouse gas $\left(\mathrm{CO}_{2}\right.$, $\mathrm{CH}_{4}, \mathrm{~N}_{2} \mathrm{O}$ ) emissions to the atmosphere from a small lowland stream in Czech Republic. Arch. Hydrobiol. 165, 339-353. doi: 10.1127/0003-9136/2006/01650339

Janssen, P. H., and Frenzel, P. (1997). Inhibition of methanogenesis by methyl fluoride: studies of pure and defined mixed cultures of anaerobic bacteria and archaea. Appl. Environ. Microbiol. 63, 4552-4557.

Jones, J. B., Holmes, R. M., Fisher, S. G., Grimm, N. B., and Greene, D. M. (1995). Methanogenesis in Arizona, USA dryland streams. Biogeochemistry 31, 155-173. doi: 10.1007/BF00004047

Kemnitz, D., Chin, K. J., Bodelier, P., and Conrad, R. (2004). Community analysis of methanogenic archaea within a riparian flooding gradient. Environ. Microbiol. 6, 449-461. doi: 10.1111/j.1462-2920.2004.00573.x

Kotsyurbenko, O. R., Glagolev, M. V., Nozhevnikova, A. N., and Conrad, R. (2001). Competition between homoacetogenic bacteria and methanogenic archaea for hydrogen at low temperature. FEMS Microbiol. Ecol. 38, 153-159. doi: 10.1111/j.1574-6941.2001.tb00893.x

Krummen, M., Hilkert, A. W., Juchelka, D., Duhr, A., Schluter, H. J., and Pesch, R. (2004). A new concept for isotope ratio monitoring liquid chromatography/mass spectrometry. Rapid Commun. Mass Spectrom. 18, 2260-2266. doi: 10.1002/rcm.1620

Kuesel, K., and Drake, H. L. (1995). Effects of environmental parameters on the formation and turnover of acetate by forest soils. Appl. Environ. Microbiol. 61, 3667-3675.
Lilley, M., De Angelis, M., and Olson, E. (1996). Methane concentrations and estimated fluxes from Pacific Northwest rivers. Mitt. Int. Ver. Limnol. 25, 187-196.

Liu, W. T., Marsh, T. L., Cheng, H., and Forney, L. J. (1997). Characterization of microbial diversity by determining terminal restriction fragment length polymorphisms of genes encoding 16S rRNA. Appl. Environ. Microbiol. 63, 4516-4522. doi: 10.1029/2012GB004306

Lueders, T., Chin, K. J., Conrad, R., and Friedrich, M. (2001). Molecular analyses of methyl-coenzyme $\mathrm{M}$ reductase alpha-subunit $(\mathrm{mcr} A)$ genes in rice field soil and enrichment cultures reveal the methanogenic phenotype of a novel archaeal lineage. Environ. Microbiol. 3, 194-204. doi: 10.1046/j.1462-2920.2001.00179.x

Ma, K., Conrad, R., and Lu, Y. H. (2012). Responses of methanogen mcrA genes and their transcripts to an alternate dry/wet cycle of paddy field soil. Appl. Environ. Microbiol. 78, 445-454. doi: 10.1128/AEM.06934-11

Martens, C. S., Kelley, C. A., Chanton, J. P., and Showers, W. J. (1992). Carbon and hydrogen isotopic characterization of methane from wetlands and lakes of the Yukon-Kuskokwim Delta, Western Alaska. J. Geophys. Res. Atmos. 97, 16689-16701. doi: 10.1029/91JD02885

Moura, J. M. S., Martens, C. S., Moreira, M. Z., Lima, R. L., Sampaio, I. C. G., Mendlovitz, H. P., et al. (2008). Spatial and seasonal variations in the stable carbon isotopic composition of methane in stream sediments of eastern Amazonia. Tellus 60B, 21-31. doi: 10.3402/tellusb.v60i1.16889

Musenze, R. S., Werner, U., Grinham, A., Udy, J., and Yuan, Z. G. (2014). Methane and nitrous oxide emissions from a subtropical estuary (the Brisbane River estuary, Australia). Sci. Total Environ. 472, 719-729. doi: 10.1016/j.scitotenv.2013.11.085

Ortiz-Llorente, M. J., and Alvarez-Cobelas, M. (2012). Comparison of biogenic methane emissions from unmanaged estuaries, lakes, oceans, rivers and wetlands. Atmos. Environ. 59, 328-337. doi: 10.1016/j.atmosenv.2012.05.031

Penning, H., Claus, P., Casper, P., and Conrad, R. (2006). Carbon isotope fractionation during acetoclastic methanogenesis by Methanosaeta concilii in culture and a lake sediment. Appl. Environ. Microbiol. 72, 5648-5652. doi: 10.1128/AEM.00727-06

Penning, H., and Conrad, R. (2006). Carbon isotope effects associated with mixedacid fermentation of saccharides by Clostridium papyrosolvens. Geochim. Cosmochim. Acta 70, 2283-2297. doi: 10.1016/j.gca.2006.01.017

Penning, H., and Conrad, R. (2007). Quantification of carbon flow from stable isotope fractionation in rice field soils with different organic matter content. Org. Geochem. 38, 2058-2069. doi: 10.1016/j.orggeochem.2007.08.004

Ramakrishnan, B., Lueders, T., Dunfield, P., Conrad, R., and Friedrich, M. W. (2001). Archaeal community structures in rice soils from different geographical regions before and after initiation of methane production. FEMS Microbiol. Ecol. 37, 175-186. doi: 10.1111/j.1574-6941.2001.tb00865.x

Rui, J. P., Qiu, Q. F., and Lu, Y. H. (2011). Syntrophic acetate oxidation under thermophilic methanogenic condition in Chinese paddy field soil. FEMS Microbiol. Ecol. 77, 264-273. doi: 10.1111/j.1574-6941.2011.01104.x

Rulík, M., Bednarík, A., Mach, V., Brablcová, L., Buriánková, L., Badurová, P., et al. (2013). "Methanogenic system of a small lowland stream Sitka, Czech Republic," in Biomass now - Cultivation and Utilization, ed M. D. Matovic (Rijeka: InTech), 395-426. doi: 10.5772/3437

Sanders, I. A., Heppell, C. M., Cotton, J. A., Wharton, G., Hildrew, A. G., Flowers, E. J., et al. (2007). Emission of methane from chalk streams has potential implications for agricultural practices. Freshw. Biol. 52, 1176-1186. doi: 10.1111/j.1365-2427.2007.01745.x

Schindler, J. E., and Krabbenhoft, D. P. (1998). The hyporheic zone as a source of dissolved organic carbon and carbon gases to a temperate forested stream. Biogeochemistry 43, 157-174. doi: 10.1023/A:1006005311257

Springer, E., Sachs, M. S., Woese, C. R., and Boone, D. R. (1995). Partial gene sequences for the A subunit of methyl-coenzyme M reductase $(m c r I)$ as a phylogenetic tool for the family Methanosarcinaceae. Int. J. Syst. Bacteriol. 45, 554-559. doi: 10.1099/00207713-45-3-554

Striegl, R. G., Dornblaser, M. M., McDonald, C. P., Rover, J. R., and Stets, E. G. (2012). Carbon dioxide and methane emissions from the Yukon River system. Global Biogeochem. Cycles 26, 1-11. doi: 10.1029/2012GB004306

Sugimoto, A., and Wada, E. (1993). Carbon isotopic composition of bacterial methane in a soil incubation experiment-contributions of acetate and $\mathrm{CO}_{2} / \mathrm{H}_{2}$. Geochim. Cosmochim. Acta 57, 4015-4027. doi: 10.1016/00167037(93)90350-6 
Trimmer, M., Hildrew, A. G., Jackson, M. C., Pretty, J. L., and Grey, J. (2009). Evidence for the role of methane-derived carbon in a free-flowing, lowland river food web. Limnol. Oceanogr. 54, 1541-1547. doi: 10.4319/lo.2009.54.5.1541

Valentine, D. L., Chidthaisong, A., Rice, A., Reeburgh, W. S., and Tyler, S. C. (2004). Carbon and hydrogen isotope fractionation by moderately thermophilic methanogens. Geochim. Cosmochim. Acta 68, 1571-1590. doi: 10.1016/j.gca.2003.10.012

Wang, D. Q., Chen, Z. L., Sun, W. W., Hu, B. B., and Xu, S. Y. (2009). Methane and nitrous oxide concentration and emission flux of Yangtze Delta plain river net. Sci. China Ser. B Chem. 52, 652-661. doi: 10.1007/s11426-009-0024-0

Youngblut, N. D., Dell'Aringa, M., and Whitaker, R. J. (2014). Differentiation between sediment and hypolimnion methanogen communities in humic lakes. Environ. Microbiol. 16, 1411-1423. doi: 10.1111/1462-2920.12330

Yuan, Y. L., Conrad, R., and Lu, Y. H. (2011). Transcriptional response of methanogen mcrA genes to oxygen exposure of rice field soil. Environ. Microbiol. Rep. 3, 320-328. doi: 10.1111/j.1758-2229.2010.00228.x

Zaiss, U. (1981). Seasonal studies of methanogenesis and desulfurication in sediments of the River Saar. Zentralblatt Fur Bakteriologie Mikrobiologie Und Hygiene I Abteilung Originale C-Allgemeine Angewandte Und Okologische Mikrobiologie 2, 76-89.
Zeleke, J., Lu, S. L., Wang, J. G., Huang, J. X., Li, B., Ogram, A. V., et al. (2013). Methyl coenzyme M reductase A ( $\mathrm{mcrA}$ ) gene-based investigation of methanogens in the mudflat sediments of Yangtze River Estuary, China. Microb. Ecol. 66, 257-267. doi: 10.1007/s00248-0120155-2

Zinder, S. H., and Koch, M. (1984). Non-aceticlastic methanogenesis from acetate acetate oxidation by a thermophilic syntrophic coculture. Arch. Microbiol. 138, 263-272. doi: 10.1007/BF00402133

Conflict of Interest Statement: The authors declare that the research was conducted in the absence of any commercial or financial relationships that could be construed as a potential conflict of interest.

Copyright $\odot 2015$ Mach, Blaser, Claus, Chaudhary and Rulik. This is an openaccess article distributed under the terms of the Creative Commons Attribution License (CC BY). The use, distribution or reproduction in other forums is permitted, provided the original author(s) or licensor are credited and that the original publication in this journal is cited, in accordance with accepted academic practice. No use, distribution or reproduction is permitted which does not comply with these terms. 